University of Nebraska - Lincoln

DigitalCommons@University of Nebraska - Lincoln

"Every Body Sees the Theft": Fanny Fern and Literary

Proprietorship in Antebellum America

Melissa J. Homestead

University of Nebraska - Lincoln, mhomestead2@Unl.edu

Follow this and additional works at: https://digitalcommons.unl.edu/englishfacpubs

Part of the English Language and Literature Commons, and the Feminist, Gender, and Sexuality

Studies Commons

Homestead, Melissa J., "'Every Body Sees the Theft": Fanny Fern and Literary Proprietorship in Antebellum America" (2001). Faculty Publications -- Department of English. 51.

https://digitalcommons.unl.edu/englishfacpubs/51

This Article is brought to you for free and open access by the English, Department of at DigitalCommons@University of Nebraska - Lincoln. It has been accepted for inclusion in Faculty Publications -- Department of English by an authorized administrator of DigitalCommons@University of Nebraska - Lincoln. 


\section{"Every Body Sees the Theft": Fanny Fern and Literary Proprietorship in Antebellum America}

MELISSA J. HOMESTEAD

$\mathrm{I}^{\mathrm{N}}$

Walden, Henry David Thoreau complained of what he believed to be the provincial reading habits of his Concord neighbors: "If we will read newspapers, why not skip the gossip of Boston and take the best newspapers in the world at once?to not be sucking the pap of 'neutral family' papers, or browsing the 'Olive Branches' here in New England."' While Thoreau's own Week on the Concord and Merrimack Rivers failed to find a national audience, he misreads (or willfully misrepresents) the potential geographic reach of authors who published in the Olive Branch, the weekly paper that launched Fanny Fern's career as a national mass cultural phenomenon. Every week in Boston in $185^{1}$ and $185^{2}$, as Thoreau was laboring over his revisions of Walden in Concord, Fanny Fern wrote short newspaper sketches in a variety of modes addressing all members of the average middle-class family-short and scathing satirical sketches of social types, flirtatious "letters" addressed to her editor and her male admirers, sentimental stories of the deaths of young children, sprightly confidential chats with married women about the foibles of the typical husband, and instructive tales directed at young readers. Once the Olive Branch and

I would like to thank Nancy Bentley, Peter Conn, Jeannine DeLombard, Leigh Edwards, Christopher Looby, Linda Smith Rhoads, an anonymous reader for NEQ, and conference panel audiences at the American Studies Association and the Society for the History of Authorship, Reading, and Publishing for comments on earlier versions of this essay. The research and writing of this essay was supported by Peterson and Mellon Post-Dissertation Fellowships at the American Antiquarian Society.

${ }^{1}$ Henry David Thoreau, Walden (1854), ed. J. Lyndon Shanley (Princeton: Princeton University Press, 1989), p. 109. 
later the True Flag published her works for the consumption of their Boston area subscribers, her works quickly moved beyond this localized audience through the mechanism of reprinting, finding their way into both other weekly papers (essentially weekly magazines published in a newspaper format) and into daily newspapers across the country. ${ }^{2}$

At this early stage of her career, Fanny Fern proved an astute player at the game of so-called exchange publication. Rather than engage in more typical strategies of "feminine" authorial self-effacement, she repeatedly drew attention to her popularity and played with the dangers of literary proprietorship. She exposed how writers in the newspapers she "wrote for" as well as those reprinting her sketches poached on what she considered to be her "property," including her persona and writing

\footnotetext{
${ }^{2}$ Scholars have recently focused attention on Fern's newspaper sketches as they appeared in the New-York Ledger or as she collected them for book publication. See, e.g., Nicole Tonkovich, Domesticity with a Difference: The Nonfiction of Catharine Beecher, Sarah J. Hale, Fanny Fern, and Margaret Fuller (Jackson: University Press of Mississippi, 1997), pp. 25-71; Joyce Warren, "Uncommon Discourse: Fanny Fern and the New-York Ledger," in Periodical Literature in Nineteenth-Century America, ed. Kenneth M. Price and Susan Belasco Smith (Charlottesville: University Press of Virginia, 1995), pp. 51-68; Laura Laffrado, "I Thought from the Way You Writ, That You Were a Great Six-Footer of a Woman': Gender and the Public Voice in Fanny Fern's Newspaper Essays," in In Her Own Voice: Nineteenth-Century American Women Essayists, ed. Sherry Lee Linkon (New York: Garland, 1997), pp. 81-96; and Claire C. Pettengill, "Against Novels: Fanny Fern's Newspaper Fictions and the Reform of Print Culture," American Periodicals 6 (1996): 61-91. Few scholars, other than Warren in the context of her biography of Fern (Fanny Fern: An Independent Woman [New Brunswick: Rutgers University Press, 1992]), have sought out Fern's early sketches in their periodical contexts. Their failure to do so is understandable: the Olive Branch and the True Flag have never been microfilmed, and among the very few copies available in libraries, only the runs at the American Antiquarian Society in Worcester, Mass., are (nearly) complete for the years of Fern's employment. This situation has led scholars to quote those of Fern's early pieces that do not appear in Fern Leaves (first or second series) from the unauthorized Life and Beauties collection. See, e.g., Lauren Berlant, "The Female Woman: Fanny Fern and the Form of Sentiment," American Literary History 3 (1991): 429-54.

Michael Newbury's discussion of Fanny Fern and literary property (Figuring Authorship in Antebellum America [Chicago: University of Chicago Press, 1997], pp. 186-99) does not take notice of Fern's early periodical career (except as it is represented in Ruth Hall). Nor does he discuss Life and Beauties or the implications of Fern's marital status for Parton v. Fleming (see below). As a result, he misses many of the complexities of Fern's literary proprietorship.

Until the last section of this essay, I will refer to the author of the sketches and of Ruth Hall as Fanny Fern or Fern, her consistent public identity during these years. I will also occasionally refer to "Fanny" (with quotation marks) to indicate a particular satiric first-person persona Fern used in her sketches.
} 
style. These "violations" of her self and her property, figured by both her and those who wrote about her in explicitly gendered terms, marked her status as a hot commodity.

Fern was more savvy than most in exploiting this often chaotic whirl of reprinting to her own benefit, but the exchange system always represented both an opportunity and a threat. In 1854, Fern published an autobiographical novel, Ruth Hall, in an attempt to capitalize on her fame and, I will argue, to stabilize an authorial persona fractured and unstable in the periodical context. The strategy produced some unintended results, not least of which was the appearance in February 1855 of an unauthorized volume, The Life and Beauties of Fanny Fern, that sought to undermine the new persona Fern was trying to construct. The presence in the marketplace of two competing representations of Fanny Fern was only partially resolved in 1856 when she took legal action to squelch yet a third text laying claim to her authority, the Fanny Fern Cookbook. Her successes as well as her failures point to the precarious status of the author in mid-nineteenth-century America.

\section{"Does Any but the Genuine Coin Ever Get Counterfeited?"}

By means of the loosely organized "system" of exchange publication, newspaper editors reprinted pieces from each other's papers and, as compensation for the privilege, offered source credit and occasional "puffs," paragraphs praising the newspaper from which the item had been borrowed. ${ }^{3}$ Beyond freely

\footnotetext{
${ }^{3}$ For a good recent discussion of the exchange system and its effects on the circulation of literary works during the nineteenth century, see Charles Johanningsmeier, Fiction and the American Literary Marketplace: The Role of the Newspaper Syndicates, 1860-190o (New York: Cambridge University Press, 1997), chap. 2. On the postal regulations that enabled postage-free mailing of newspapers between editors, see Richard B. Kielbowicz, News in the Mail: The Press, Post Office, and Public Information, 1700-186os (New York: Greenwood Press, 1989). On the spread of news (as opposed to literary) text through the exchange system, see Richard R. John, Spreading the News: The American Postal System from Franklin to Morse (Cambridge: Harvard University Press, 1995). On Edgar Allan Poe's clever manipulation of the system in his "Autography" series, see Meredith L. McGill, "The Duplicity of the Pen," in Language Machines: Technologies of Literary and Cultural Production, ed. Jeffrey Masten, Peter Stallybrass, and Nancy J. Vickers (New York: Routledge, 1997).
} 
reprinting and circulating text, editors and correspondents also carried on discussions in the periodical press about the mechanisms of exchange and circulation, especially when the "system" broke down, as it often did. Fern went a step further. She incorporated that dynamic into her sketches, using them to comment explicitly on the material conditions of their circulation.

In the first two papers carrying Fern's columns, the Olive Branch and the True Flag, violations of the extra-legal code governing reprinting were frequently a subject of editorial comment. For instance, in 1853 the editor of the True Flag reprinted a brief letter from Fern to the editor of the Evening Transcript correcting his assertion that she "wrote for" another Boston paper:

The above communication, which appeared in the Evening Transcript, was rendered necessary by a mean and dishonest claim made by a contemporary, and advertised in the Boston dailies, that Fanny Fern was a contributor to his paper. He steals her literary reputation, without rendering her any equivalent; although she never wrote a line for him, and he knows that she is strongly opposed to any such disreputable use of her name, in connection with his paper. A man who would deal thus basely with a lady, and build up his own success on her popularity, would not scruple to sell his own grandmother to a soap-maker, for five dollars. ${ }^{4}$

Despite the threat to her reputation, Fern's position in the contest is secure. As each editor fights for the right to build his own popularity on a claim of enabling hers, her popularity remains unquestioned. Still, her popularity is most clearly evident through repeated, dishonorable encroachments on her reputation. The more widely her sketches are reprinted, the more frequently strange men claim false alliances with her, making her look like a woman of easy virtue. Therefore, her popularity is inseparable from a chronic crisis of authorial reputation, the type of crisis to which Fern, as a "lady," is particularly susceptible. Circulation of her sketches remains, after the moment 
when she transfers her manuscripts to an editor so that they can appear in print, largely beyond her command, and that circulation always threatens to spiral out of control. As an unaccompanied lady in the marketplace, implies the editor of the True Flag, Fern must rely on his vigilance and his efforts to protect her reputation. It is a theme Fern mines time and again-seriously, humorously, playfully-in the course of her career as a periodical writer.

Many of Fern's early sketches take the form of "letters" written to her editors, whether "Dear Mr. Norris" (William Norris, editor of the Olive Branch) or "Dear Mr. True Flag" (William Moulton, who served anonymously as the editor of the True Flag), protesting editorial action (or inaction) affecting her reputation. Particularly in the Olive Branch, which published more reader correspondence and other self-referential commentary than the True Flag, readers often adopted their own pseudonyms and personae to engage Fern's satiric "Fanny" persona in discussion, competition, and particularly flirtation. Whether or not these readers' letters are authentic, they have the effect of making "Fanny" the center of attention and controversy, much of it sexually charged.

Marriage proposals flooded into the office in response to a "letter" she addressed to Norris in the 31 January $185^{2}$ Olive Branch. In another of her "letters" published in the same issue, a rebuff to "Eva," a female reader seeking her friendship, "Fanny" claims that "women never make decent friends to their own sex." Anticipating an indignant response from women readers, she solicits Norris's protection.

My Dear Mr. Norris-May I venture to hope you don't wear a jacket, for I must hold on to the skirt of somebody's coat after stirring up such a hornet's nest of women. . . . Now you know how nicely I got out of that scrape with Mr. Carpet-Bag, when I meddled with his old lady Partington. He shut up my mouth with such a big sugar plum that I've never opened it since to wag my tongue or pen against her or "Ike" but these women, with their squibs and crackers, will keep peppering away at me until the millenium [sic], if you don't put a stop to it. See what it is to be a lone unprotected female. I shall have to get married, that's a fact. 
"Mr. Carpet-Bag” was Benjamin Shillaber, a writer of humorous periodical sketches and, in January $185^{2}$, the editor of a recently established (and ultimately short-lived) weekly humor magazine The Carpet-Bag (which, careful readers of the Olive Branch would have known, was published from the same Boston office building as "Dear Mr. Norris's" newspaper). ${ }^{5}$ Shillaber's most famous creation was "Mrs. Partington," a sort of Yankee Mrs. Malaprop, whose unintentionally humorous sayings became fodder for "squibs" reprinted in papers throughout the country. Mrs. Partington was the widow of the departed "Corporal" Paul Partington (a member of the local militia during the War of 1812), and "Ike" Partington was her orphaned nephew and adopted son. ${ }^{6}$ Although "Fanny" doesn't specify exactly how she "meddled with [Shillaber's] old lady Partington," it seems likely that he resented Fern's imitation of Mrs. Partington's style in her 22 November 1851 sketch in the Olive Branch, "Aunt Charity's Advice to Her Nephew on Leaving Smithville." Assuming the character of a rural, Yankee old maid, Fern peppered her "soliloquy" with "Partington-isms." "[I]f my remission had been asked," says Charity to her nephew, "you never-d ha-went" to Boston. She warns him of the "proomiskus" nature of boarding-house food, and tells him what to do with boardinghouse "sasenges" (sausages): "es-chew

${ }^{5}$ On 5 July 1851, a week after Fern's first appearance ( 28 June 1851 ) in the Olive Branch under the signature "Clara" and just after the Carpet-Bag began publication, Norris published a paragraph entitled "Partington Courtesies," describing a bouquet of roses purportedly sent to the Olive Branch offices by Mrs. Partington herself. On 27 December 1851, the Olive Branch published an extended "puff" of the Carpet-Bag that identified Shillaber as "the original Mrs. Partington" and the "principal editor." This puff appeared about a month after the Aunt Charity sketch described below, leading me to believe that the puff may have been the penalty Shillaber demanded from Norris for Fern's imitation of Mrs. Partington's style.

${ }^{6}$ Shillaber's early Partington newspaper paragraphs are collected in The Life and Sayings of Mrs. Partington (New York: J. C. Derby, 1854). Mrs. Partington first appeared in the Boston Post in 1847 , where Shillaber, previously a compositor, was editor of the "All Sorts of Paragraphs" column. Mrs. Partington's "squibs" on current events or new fads were widely reprinted. For brief accounts of Shillaber's works and career, see Clyde G. Wade, "B. P. Shillaber," in Dictionary of Literary Biography: American Humorists, 1800-1950, ed. Stanley Trachtenberg (Detroit: Gale, 1982) and Daniel G. Royot, "B. P. Shillaber," in Encyclopedia of American Humorists, ed. Steven H. Gale (New York: Garland, 1988). 
'em." Although Fern went on to adopt many voices and personae in subsequent columns, she never revived Aunt Charity or her distinctive (but not original) style of speaking.

Just as "Mr. Carpet-Bag" defended his turf, the distinctive comic style that made "Mrs. Partington" a national figure, "Fanny" asked Norris to help her defend "hers." In July 1852, again invoking their run-in with Shillaber, "Fanny" protested imitations of "Fanny." Norris writes that she called on him in person, asking him to reveal the true identity of "Sweet Pea," a contributor "Fanny" accuses of poaching. When Norris refuses to divulge the information, "Fanny" writes him "the following rather caustic letter":

Dear Mr. Norris: You remember how touchy Mr. Carpet Bag was when I got up a spurious Mrs. Partington? Well, you said I mustn't, and I didn't! (any more;) and now just please strangle in the birth any embryo imitations of Miss "Fanny," won't you? It seems to me just as fair in this case as the other. I shall turn John, or Sam, or something, I know, if you don't! for it makes me cross! I do think you are just like all the rest of mankind, and love to tease! How can you? Do be good to me now? You don't know how awfully you frighten me when you look so stern; I don't know whether to run away or cry. Yours affectionately, FANNY [3 July 1852]

Norris concedes "Fanny's" point, charging that it is

a sort of piracy to assume the peculiar style of any popular writer. It is precisely the same as merchants or manufacturers appropriating each other's trade marks without the consent of the owner-besides, those who assume other people's style of writing, never come up to the original. ... We shall therefore discourage our contributors from borrowing each other's styles of writing.

Norris's analogy to trademark infringement is telling. A trademark does not recognize a company's claim to something new and original, like a machine granted patent protection by virtue of its truly innovative character. Instead, with trademark, a company adopts a word or symbol not currently used by its competitors and then establishes, through its exclusive use in the marketplace, a connection in consumers' minds between 
that mark and the company as a source of a particular product. ${ }^{7}$ At stake in the feud over alleged misappropriations of Fanny Fern's style is not true originality, a distinctive personal quality that cannot be replicated; rather, "Fanny" seeks to "mark" a particular segment of the market as hers by excluding others from assuming "her" style of expression.

The issue of style as trademark reemerges several months later in the Olive Branch. Fern responds to a published letter signed by "Harry Honeysuckle," another Olive Branch contributor who protests that he is not one of those scoundrels mimicking her style; indeed, his style has been stolen too. Not persuaded, "Fanny" accuses him of imitating her "models":

Did you know, my dear "Honeysuckle," that plants sometimes choke each other? You'll die of Fern-strangle one of these days, if you don't leave off shooting round a corner at my "Model" factory! Don't you suppose I see the spurious models? Don't you suppose every body else sees them? and does any but the genuine coin ever get counterfeited, hey? Don't I appreciate the unintentional compliment? "Steal my thunder"? They can't do it Harry. It has "my mark" on it. Every body sees the theft. You'd better let me alone, "Harry," if you don't want to be a "FIXED" ! [ 16 October 1852]

Fern's use of the word "model" is a pun on a series of sketches she published in the Olive Branch, each using the word "Model" in the title as an adjective describing either the best or the worst of a class of people. For instance, her negative "Model Lady" "Puts her children out to nurse and tends lapdogs," and her positive "Model Boarder" "Goes through the catechism to his landlady without a wry face" (24 April 1852). Fern extended the series from April through August, which implies that it was popular with readers, and the brevity of the sketches made them ready targets for reprinting. By imitating her "models," Harry had thus tried to insinuate himself into a patch she had earlier cultivated and the luxuriant greenery of

${ }^{7}$ For a brief overview of the historical development of trademark law, see J. Thomas McCarthy, McCarthy on Trademarks and Unfair Competition, 3d ed. (Deerfield, Ill.: Clark Boardman Callaghan, 1996), chap. 5 . 
which she is still harvesting. Harry, in short, is not welcome to hoe the same plot.

Even as Fern threatens to "fix" Harry for his production of "spurious models," she acknowledges the implicit compliment of his theft, which, because obvious to "every body," concedes the superiority of her talent. For those who have not seen the theft, she draws their attention to it, and thus draws attention to the desirability of her style as a "model"; that is, she berates Harry Honeysuckle's production of a "spurious Fern" to promote the consumption of models properly marked by the name Fanny Fern.

\section{"What's in a Name?"}

"What's in a name?" asks the Musical World \& Times, the third paper to employ Fern, in a review of her first juvenile book, Little Ferns. Reporting a delay in the publication of the book due to heavy advance demand, the World answers its own question: "[T]he name of FANNY FERN alone commanded this unprecedented sale. What, then, is in a name? It would seem that there are a great many thousand dollars in some names" (1o December 1853). As Fern added successful book publication to her career of newspaper publication, she and her editors increasingly condemned encroachments on her name as well as her style. Typical infractions included: reprinting her articles without providing her byline; reprinting her articles under the name of another writer; attributing to Fern articles not written by her; and falsely reporting that she was writing articles under other pseudonyms.

\footnotetext{
${ }^{8}$ Articles reprinted without Fern's name include "Beautiful Sentiment," described below, and "Two in Heaven" (Arthur's Home Gazette, 29 January 1853), credited to the Olive Branch but not to Fanny Fern. The 9 July 1853 Musical World \& Times castigates the Home Journal, edited by Fern's estranged brother, N. P. Willis, and/or its contributor Grant Thornburn, for passing off a Fanny Fern sketch as "Laurie Todd on Spinsters." (In fact, on 25 June 1853, the Home Journal did run Fern's 3 July $185^{2}$ untitled Olive Branch article, attributing it to Grant Thornburn writing as "Laurie Todd"). The 9 April 1853 Musical World \& Times calls the attribution to Fern of a piece entitled "Gentlemanly Accomplishments" an "atrocious libel." On claims that Fanny Fern wrote under other pseudonyms, see her letter in the 12 March 1853 issue of the True Flag: "MR. EDITOR:-Will you oblige by saying to your readers that I never write for any publication over any other signature than that of FANNY FERN." Such letters were subsequently published in the New-York Ledger after Fern began writing there.
} 


\section{FANNY FERN AND LITERARY PROPRIETORSHIP 219}

In a laudatory, unsigned review in the Musical World in May 1853, most likely by its editor and Fern's brother Richard Storrs Willis, the writer makes rather extravagant claims about the originality of Fern's style.

Imitators are mere satellites; and, in the nature of things, they can never rise to an equality with the central luminary around which they revolve and from which they derive their twilight radiance. They are useful, however; inasmuch as their vapidness serves admirably as a foil to the excellence of the brilliant original; the contrast rendering the beauties of the model all the more apparent and enjoyable. Fanny Fern can succeed in this style, but her imitators cannot: with her it is natural; with them it is assumed. Style (as Carlyle might express it) is an objective manifestation of one's subjectivity-it is the form of the mind,--it must fit the thought as the skin fits the body; and it is just as ridiculous to "try on" another's style as it would be to try on another's skin. [28 May 1853 ]

The metaphor of body and skin seeks to stabilize and naturalize Fern's presence in the periodical marketplace. In an essentially unstable environment-in which sketches are reprinted and reprinted again, with the inevitable accretion of errors, changes, and edits-however, Fern's subjectivity is as fluid as the shifting representations of her thoughts rendered into type. Would the reader of a tenth-generation reprint of one of her paragraphs have encountered the "same" Fern-y subjectivity as a reader of the World? And exactly how could readers discern the "objective" nature of the subjectivity of a woman whose true identity was, in early 1853 , still not generally known?

Even Fanny Fern's editors, those who were presumably most intimately acquainted with the author and her style, fell prey to the confusion made inevitable by reprinting. In the 1 October 1853 Olive Branch, for example, the editor printed a letter from a reader, G. L. Lane, asking about a sentimental sketch, "Crushed Jewels," describing the death of young children and appearing in a Boston daily that credited it to Fanny Fern. Lane points out that the article was previously published in the Olive Branch under the name of Patience Pepper, and he asks, "Does Fanny use other people's good things, or is this the work of other hands?" The editor sheepishly responds: 
Our correspondent is just in time with his correction, as we need blowing up quite as much as anybody in the matter. We saw the article in question in the Herald, and supposing it one of Fanny Fern's from her book, we transferred it to the columns of the fourth page of this paper, where those who have never seen it, can admire it, and give credit where it belongs-viz: to our gifted correspondent "Patience Pepper." We stand pretty much in the same attitude of the newspaper-man who copied his own editorials.

A reader turning to the Ladies' Department on page four sees, uncorrected, the text of "Crushed Jewels" attributed to Fanny Fern. ${ }^{9}$ Once Fanny Fern's name has been affixed to an item by someone else, admits Norris, he is powerless to distinguish between his own contributors. Indeed, as he admits, in the shifting waves of exchanged text, editors sometimes cannot identify their own skins, let alone those of their contributors, and fall prey to reprinting their own editorials as if they were by someone else.

In June 1853 , Fern stopped contributing pieces to the Olive Branch, and by the end of the year, when it became clear that she did not intend to resume contributing original materials, the paper also stopped reprinting her sketches from other periodicals. After the publication of her novel Ruth Hall at the end of 1854 , with its unflattering fictionalized portrait of the Olive Branch, the paper became actively hostile to Fern's work. By 1855, Fern was under contract to write exclusively for Robert Bonner's New-York Ledger for a tidy weekly salary. In a paragraph entitled "Sour Grapes" in its 8 March $185^{6}$ issue, the Ledger smugly dismissed the Olive Branch:

\footnotetext{
${ }^{9}$ As a four-page paper printed on a single, folded sheet, the Olive Branch clearly set pages one and four (one side of the sheet) before pages two and three (the other side of the sheet). Correcting the erroneous attribution as printed on page four would have forced Dyer to sacrifice an entire print run. Mr. Lane accurately specifies that the misidentified reprint appeared in the "[Boston] Daily Herald, for Sept. 21st." "Crushed Jewels" appeared in the Olive Branch under "Patience Pepper's" name on 10 July 1852 . Fanny Fern no longer wrote for the Olive Branch in October 1853, so Norris only had access to Fern's work through reprinting, and his mistake provided, ironically, a chance to puff the work of someone who was still writing for his paper by pointing out that she was "gifted" enough for her writing to be mistaken for Fern's.
} 
By the way, one of FANNY'S articles which we published a few weeks ago, and which was extensively copied in the country papers, without her name being attached to it, appeared in the Olive Branch last week under the caption "A BEAUTIFUL SENTIMENT." The Olive Branch . . . is the most bitter enemy FANNY has in the newspaper field, and yet it compliments her writings when her name is not connected with them, and the editor does not suspect her to be the author.

In this instance, the presence or absence of Fern's name alters the identity of the unchanged textual artifact, making it acceptable or unacceptable, worthy or unworthy of reprinting depending on what the editor thinks of Fanny Fern. Her name, or lack thereof, thus powerfully shaped the circulation and reading of her texts. ${ }^{10}$

\section{"They Must Purchase Themselves out of Bondage"}

At a number of crucial moments in Fern's novel Ruth Hall, the eponymous heroine is faced with threats to her ability to control the reproduction and circulation of her newspaper sketches. Early in her career, she is introduced to exchange publication and its implications for her career. Later, as she is preparing a collection of her sketches, her disgruntled former editor, Mr. Tibbets, threatens to "immediately get out a cheap edition of your articles, and spoil the sale of your book." Ruth, initially compliant because she was desperate to gain entrée into writing as a profession, uses this opportunity to assert her independence as an author (although her self-assertion instead, paradoxically, confirms her publisher's rights to her book). She tells Tibbets that she will not be "frightened, or threatened, or

\footnotetext{
${ }^{10}$ The New-York Ledger published its smug comment with remarkable speed, the same day, in fact, that the Olive Branch published "A Beautiful Sentiment." My framing of this discussion has been influenced by Foucault's remarks in "What is an Author": "the name seems always to be present, marking off the edges of the text, revealing, or at least characterizing, its mode of being. The author's name manifests the appearance of a certain discursive set and indicates the status of the discourse within a society and culture" (in The Foucault Reader, ed. Paul Rabinow [New York: Pantheon, 1984], p. 107). However, as Parton v. Fleming suggests, Foucault's assertion that "It [the author's name] has no legal status" fails to account for the possibility of an author's name functioning as a trademark.
} 
insulted": "Even had I not myself the spirit to defy you . . you could not accomplish your threat; for think you my publishers will tamely fold their arms, and see their rights infringed? No, sir, you have mistaken both them and me."

A short time before this scene, Ruth, whose pseudonym has effectively hidden her real identity, reads and sorts through a bundle of fan letters forwarded to her by her editor. Among the letters that hold no interest for her is one from a Southern reader proposing marriage. $\mathrm{He}$

confessed to one hundred negroes, "but hoped that the strength and ardor of the attachment with which the perusal of her articles had inspired him, would be deemed sufficient atonement for this in her Northern eyes. . . Would she not smile on him? She should have a box at the opera, a carriage, and servants in livery, and the whole heart and soul of Victor Le Pont." [Pp. 152-53]

A letter from a book publisher regarding the collection of sketches noted above offers her a choice in the arrangement: she can receive either a one-time fee of $\$ 800$ or a royalty per copy sold. Ruth, who has metamorphosed from a married economic innocent into a widowed, shrewd businesswoman during the course of the novel, weighs the evidence of her popularity, including her fan letters, against the security of $\$ 800$ in hand and decides to take a risk. She bangs her fist on the table and declares that her book "shall!" sell enough to repay the risk many times over (p. 153). The juxtaposition of the two letters, one offering marriage and the other a business deal, is telling. The choice for Ruth is stark: either remarry and become little more than a high-class slave, or maintain economic independence and absolute self-possession through authorship. ${ }^{12}$

\footnotetext{
${ }^{11}$ Fanny Fern, Ruth Hall and Other Writings, ed. Joyce Warren (New Brunswick: Rutgers University Press, 1986), p. 157. All subsequent citations to Ruth Hall will be to this edition and will appear in the body of the essay.

${ }^{12}$ Modern critical readings of $\mathrm{Ruth}$ Hall have tended to fall into three categories: those that emphasize the conflict between the sentimental and satiric elements of the novel as evidence of Fern's own conflicted attitudes towards authorship (see Mary Kelley, Private Woman, Public Stage: Literary Domesticity in Nineteenth-Century America [New York: Oxford University Press, 1984]; Linda Huf, A Portrait of the Artist as a Young Woman: The Writer as Heroine in American Literature [New York: Ungar, 1983]; and Ann D[ouglas] Wood, 'The 'Scribbling Women' and Fanny Fern: Why Women Wrote," American Quarterly 23 [1971]: 3-24); those that see the satiric ele-
} 
FANNY FERN AND LITERARY PROPRIETORSHIP 223

In her review of Ruth Hall in The Una, Elizabeth Cady Stanton emphasized Ruth's trajectory from the slavery and dependence of marriage and of widowhood before she began writing to her eventual self-possession through paid labor:

The great lesson taught in Ruth Hall is that God has given to woman sufficient brain and muscle to work out her own destiny unaided and alone. Her case, like ten thousand others, goes to prove the common notion that God made woman to depend on man, a romance, and not a fact of every-day life. ${ }^{13}$

Most reviewers, including another for The Una, Caroline Healy Dall, read the narrative as autobiography, and they attacked Fern for her unwomanly public censure of her family through her satiric novelistic portrayals of them. Stanton, however, proclaimed that the story of Ruth's life should be read with the same respect accorded a slave narrative. Rebuking the writer of a negative review of Ruth Hall in the Anti-Slavery Standard, Stanton instructs the readers of The Una to

Read "Ruth Hall," as you would read the life of "Solomon Northrup," a Frederick Douglass, - as you would listen to the poor slaves in our anti-slavery meetings. ... The next mulatto slave that comes North, and gets upon a platform, to tell of the cruelty and injustice of his $f a-$ ther and brethren, hiss him down,-read him the laws of the Mohammedans and Christians on "filial irreverence."14

ments subverting the sentimental elements (see Susan K. Harris, Nineteenth-Century American Women's Novels: Interpretive Strategies [New York: Cambridge University Press, 1990]; Nancy Walker, Fanny Fern [New York: Twayne, 1993]; and Warren, Fanny Fern); and readings that explore and historicize the complicity of sentimentality with commodity capitalism (Berlant, "Female Woman," and Richard Brodhead, Cultures of Letters: Scenes of Reading and Writing in Nineteenth-Century America [Chicago: University of Chicago Press, 1993]). Like this latter group of critics, I am less concerned with Fern's conflicted feelings about authorship or with conflicts among textual elements in the novel than with the relationship between the novel and the marketplace.

${ }^{13}$ Elizabeth Cady Stanton, "Ruth Hall," The Una, February 1855, p. 29.

${ }^{14}$ Stanton, "Ruth Hall," p. 29. It is beyond the scope of my essay to take up the clearly problematic nature of feminist analogies between chattel slavery in the South and the "slavery of sex." For a powerful critique, see Karen Sanchez-Eppler, Touching Liberty: Abolition, Feminism, and the Politics of the Body (Berkeley: University of California Press, 1993). My point here is to make clear that the analogy resonated with Fern and affected both the writing of her novel and the reading of it, at least by Stanton. See also Linda Grasso, "Anger in the House: Fanny Fern's Ruth Hall and the Redrawing of Emotional Boundaries in Mid-Nineteenth-Century America," Studies in the American 
Stanton specifies a "mulatto slave" to make clear the irony of criticizing both the slave and Fern for lack of "filial" reverence. In both cases, implies Stanton, the man vilified by the autobiographer is both oppressor and father: Fern criticizes her father for his cruelty and indifference to her after she is widowed, and the mulatto slave criticizes his cruel owner and master, who also probably fathered him by raping the slave mother.

In the language of 1850 s feminist reform, then, Fern, representing her own situation through that of her heroine, Ruth, had "purchased" herself out of bondage through her authorial labors, and she was entitled to rebuke those who had tried to keep her and other women economically "enslaved." As an address from an 1853 women's rights convention in New York (reprinted in The Una) argues, "Who ever can pay for himself, and support himself, may be free. When a man's intrinsic manhood is really worth as much as he will bring in the market, he may be his own purchaser, and pass, even under the laws of slavery from the condition of bondage to that of freedom." The speaker urges women to recognize this truth, to "go to work. They must press into every avenue, every open door, that custom and law leave unguarded, aye, and themselves withdraw the bolts and bars from others still closed against them, that they may enter and take possession. They must purchase themselves out of bondage." ${ }^{\prime 15}$ The final chapter of Ruth Hall dramatically demonstrates Ruth's own self-purchase. Her shrewd decision to forego the $\$ 800$ flat fee in lieu of royalties nets her a bank stock certificate in the amount of $\$ 10,000$. Like a slave with free papers, implies the novel, she now has independent passage in the world. ${ }^{16}$ As a woman who writes, that self-

Renaissance (New York: Twayne, 1995), pp. 251-61, for an analysis specific to Fern's novel and the Una reviews.

${ }^{15}$ P. W. Davis, "P. W. Davis's Remarks at the Convention," The Una, September 1853, pp. 136-37.

${ }^{16}$ Only as a single woman, a feme sole, however, could Ruth own the bank stock certificate in her own name, a fact that the novel does not directly address, although Fern clearly understood the legal importance of that distinction by the time she wrote the novel. Also, as Lauren Berlant effectively demonstrates by juxtaposing this moment with a similar moment in Harriet Jacobs's slave narrative, Ruth's situation is not exactly parallel to that of a slave with free papers: "Both women have struggled to procure these papers, but while the one [Jacobs's] denotes the minimal unit of freedom experi- 
FANNY FERN AND LITERARY PROPRIETORSHIP 225

possession is guaranteed by means of her secure ownership of her literary property.

\section{"I Have Read Your Heart in Your Many Writings"}

Although Ruth Hall is able to gain control of her self-representation by choosing the time and the terms in which to reveal the person behind Floy, her pseudonym, the woman behind the mask of Fanny Fern faced a more professionally complex and personally disquieting set of circumstances. Fern's early sketches offered a multiplicity of voices and identities to readers: from sentimental to satiric and all shades in between; narrated in the third person, "soliloquized" in the voice of a named character, spoken by an unidentified first person, or spoken in the first-person voice of "Fanny." Even within the identifiable persona of "Fanny," readers would have found it difficult to locate a stable character, let alone the character of the un-named writer behind the pseudonym. "Jack Plane," one of the many readers asking for "Fanny's" hand in marriage, longs to discover her true identity. She assures him that her editor will keep her secret, so

Now your only hope lies in me, and such a dance as I shall lead you! I'm a regular "Will o' the Wisp"; everything by turns, and nothing long. Sometimes I'm an old maid, sometimes a wife, then a widow, now a Jack, then a Gill [sic], at present a "Fanny." If there's anything I abominate it's sameness; no article of furniture in my premises stands in the same spot two days in succession. If I'd born a twin, I should have poisoned t'other one; and if I was married, and my husband told me he loved me, TWICE in the same words, I'd take the tongs and put him out the window. [Olive Branch, 3 March 1852]

Reprinting complicated this intentional multiplicity of personae even further. As a writer, Fanny Fern could decide to change the "self" manifested in her writings from old maid to wife or from a Jack to a Jill; but others could also change Fanny Fern

enced by an American citizen, the other denotes a successful negotiation of the national-capitalist public sphere, a profitable commodification of female pain and heroism in an emerging industry of female cultural workers" ("The Female Woman," p. 448). 
into the anonymous author of "A Beautiful Sentiment," or they could turn Patience Pepper into Fanny Fern. It is precisely this multiplicity and instability of "Fanny" as a print phenomenon that is missing from Fern's fictionalization of that experience through "Floy." While "Ruth Hall" gains full possession of her self, her identity, and her literary property, the periodical circulation of Fanny Fern's works troubled her self-possession and proprietorship and caused her identity to remain publicly suspended in a state of crisis.

The novel, however, avoids confronting this authorial instability by obscuring it, by not representing Ruth's sketches. We never actually read Ruth's articles, nor do we know precisely what they are about or what sort of style they employ. No samples or excerpts are offered, and neither the narrator nor any character ever describes an article in particular or the writings in general (with the exception, late in the novel, of an expression of surprise from an un-named man that she can write so convincingly about "poverty" when her brother claims that the family always supported her and that she was never poor). We learn all about the labor of her writing, the scratching of her pen, her throbbing brow and weary fingers, and we know what she buys with her earnings ("bread for her children"); but the novel does not represent the object produced by that work.

What we are given in lieu of the absent articles are readers' reactions to them-fan letters-many of which are "quoted" in part or "reproduced" in full in discussions of Floy's art. Readers seek her hand in marriage or a bust of her for their collections; they ask her to write for them (everything from family histories, to poems memorializing dead family dogs and infant school [i.e., nursery school] "jubilees," to school compositions) or thank her for the personal comfort they receive from her columns. While other scenes in the novel celebrate Ruth's possession of the literary text as a commodity that may be sold, the scenes of private author-reader exchange establish a zone in which domestic production and consumption exist as transactions protected from the insecurity of the marketplace.

In withholding the text of the sketches, the novel clearly intends that we should rely on those readers' responses that Ruth 
values and which she answers to understand the true nature of "Floy." Although "Fanny" warned her readers in the Olive Branch not to seek "Fanny Fern's" true character in her sketches, Ruth Hall argues that readers can find Ruth Hall in "Floy's" (absent) sketches. Floy puts aside marriage proposals and requests for her literary services, but she consistently responds to readers who feel they can read her heart in her sketches. "Mary R__," an invalid, writes to says that "every week your printed words come to me, in my sick chamber, like the ministrations of some gentle friend"; Ruth responds to Mary's letter by bowing her head and offering a "grateful prayer" (pp. 136-37). Ruth decides she must answer "Mary Andrews," the gravely ill wife of an alcoholic husband who begs "Floy" to adopt her baby when she dies. She reasons that Floy is "not a stranger, for I have read your heart in your many writings. In them I see sympathy for the poor, the sorrowing, and the dependent; I see a tender love for the helpless child" (p. 165). A letter from a man who claims to be "a better son, a better brother, a better husband, and a better father" because of "the words you have spoken (though unintentionally) so directly to me" (p. 183) prompts Ruth's "grateful" tears. Ruth's heartfelt responses to their passionate pleas confirm that they have gauged her accurately.

Unlike "Floy's" readers, who never meet Ruth Hall, John Walter, the editor of the Household Messenger, does meet Ruth, and he more firmly establishes the connection between Floy's (absent) columns and the embodied author. He reads her sketches as collectively voicing "a wail from her inmost soul," "a history of wrong, and suffering, and bitter sorrow" (p. 140), and he confirms that truth by reading it in her face. By establishing this equivalence between sketch and writer, between pseudonym 'and true identity, the novel further suggests that readers apply the same interpretive strategies to the seemingly autobiographical novel and its author. The absent presence of Floy's sketches and the presence of her more fully described body substitute for and write over the material history of Fanny Fern in print, obliterating the multiple and unstable "Fanny" by substituting the "wail from her inmost soul" and the 
body of a single woman author. Fern thus used Ruth Hall and its fictional heroine to construct a new, more stable Fanny Fern, subject to and capable of possession, proprietorship, and control, a being capable of author-izing future book and periodical manifestations.

Ruth Hall notices in passing the ways in which reprinting troubles Ruth's absolute control over the circulation of her property and her self, but in the novel the threat is minimized. As her first editor, Mr. Lescom, tells Ruth, "your very first articles are copied ... into many of my exchanges. ... A good sign for you Mrs. Hall; a good test of your popularity" (p. 130). He also notes, and then regrets telling her so when she asks for an increase in pay, that because her articles are to appear regularly in his paper, he has received subscription requests from readers in far-flung states. Although Ruth understands reprinting's usefulness as a gauge of popularity, she remains aloof from the chaotic process of exchange publication that swirls around her. She vanquishes Tibbetts, and her book conveniently allows her to move above and beyond the fray as she claims her bank-stock certificate. Appearing in multiple contexts beyond her control, her periodical sketches were received by an audience reading different newspapers pursuing different ends. With the collection, on the other hand, her audience is unified by means of the common experience of reading that one book, a volume organized and authorized by her that presents her work only in the context of other pieces written by her. In Fern's fictionalization of her career, once Ruth gains firm control over her selfrepresentation through publication of her book, her character and reputation are invulnerable to future attacks.

Sara Payson Willis Eldredge Farrington had not long to wait to discover if her strategy for stabilizing her authorial persona and literary proprietorship had succeeded. On $3^{0}$ December 1854, just a few months after publication of Ruth Hall, William Moulton, angry over his portrayal as Tibbets and still smarting from Fern's withdrawal from his newspaper, launched a smear campaign in the True Flag, a campaign that culminated in 1855 with the publication of The Life and Beauties of Fanny Fern, which revealed Sara's identity. This unauthorized, anonymously 
edited collection of Fern's newspaper sketches satirically adopted the convention of other "life and beauties" volumes, interspersing the sketches (Fern's "beauties") with critical commentary about them as well as about Ruth Hall and with vignettes constituting a scandalous biography (Fern's "life").

Despite Ruth Hall's implied claim of a legally enforceable right to foreclose publication of the cheap volume with which Tibbetts intends to ruin her, the compiler of Life and Beauties, almost certainly Moulton, ${ }^{17}$ faced no such prohibition. In the preface to the volume, the anonymous editor carefully (and for the most part correctly) explains the legality of his actions:

The lives of distinguished men or women have always been accounted public property, and, in narrating that of Fanny Fern, we have confined ourselves to simple facts, leaving fancy-pictures to be filled up by others. In giving selections from her "Beauties," we present the reader with a bouquet of "Ferns," all freshly gathered. In so doing, we have infringed no one's copy-right; the sketches having been copied, in every instance, from the paper to which they were originally contributed. ${ }^{18}$

$\mathrm{He}$ "infringed no one's copy-right" by reprinting Fern's sketches in book form because the editors of the True Flag and the Olive Branch, like many editors of weekly periodicals, did not take the steps necessary to secure copyright protection for the contents of their newspapers. More interesting than the legal technicalities is the figurative language Moulton uses to describe Fern's predicament. The "lives of distinguished men or women" are public property, but Fern's status as a woman with a public life is clearly central, making her works seem easier to appropriate and intensifying the effects of that appropriation on her reputation. Whereas "Ruth Hall" claimed the lady's right to be protected by her gentlemanly publisher, Moulton implies that Fanny Fern, as a lady tarnished by her own misconduct, is easy pickings. Ruth Hall maintains both self-

\footnotetext{
${ }^{17}$ See Warren's identification of Moulton, in Fanny Fern, p. 112. iii-iv.

${ }^{18}$ The Life and Beauties of Fanny Fern (New York: H. Long and Brother, 1855), pp.
} 
possession and privacy after the publication of her book, but after the publication of Ruth Hall, Moulton claims Fanny Fern's life and works as public property.

The backlash against Sara for revealing intimate details of her family life was personally distressing but professionally rewarding-once again, unauthorized reprinting presented both a threat and an opportunity. In the wake of the publication of Life and Beauties, sales of Ruth Hall multiplied as readers made a game of unlocking the roman à clef. Sara had laid the groundwork for converting exposure into an advantage by making the connection between the embodied author and her print manifestations public and visible in Ruth Hall. Writing every week in her own column in the New-York Ledger, a paper that did not discourage exchange reprinting of Fern's sketches but that copyrighted them and otherwise made sure that the world knew Fern wrote only for the Ledger, Sara (soon to be) Parton became Fanny Fern; and Fern, her sketches protected by copyright, regularly issued collections of those sketches and was not subjected a second time to unauthorized book reprinting of them (at least in the U.S.).

\section{Parton v. Fleming; or, Fanny Fern v. Mrs. James Parton}

The story of Fanny Fern's literary proprietorship in the 1850 os does not, however, end on a note of unambiguous triumph, even if that was her hope and intention. In 1856, Fern celebrated in a New-York Ledger column a real-world legal triumph. While the column is a ringing confirmation of her literary proprietorship, her narrative of the case bears the same complex relationship to the messy and ambiguous realities of her authorial situation in 1856 as did Ruth Hall to her situation in the early 185 os.

On 26 July 1856, under the title "An Impudent Dodge," the New-York Ledger warned its readers against a recently issued work illegitimately bearing the name of its famous columnist. Deriding the "ungrammatical preface and chapter headings" of "Fanny Fern's Family Cook Book," issued by Philadelphia publisher William Fleming, the Ledger protested that Fern had not 
authorized the book and that its publication was "an outrageous imposition" upon both Fern and her readers. "Suppose that this Philadelphia publisher were a popular author himself," asks the Ledger, "how would he like some one to use his name and place it on a book that he had never seen or heard of, in order to make it sell?" In short, the publisher had used Fern's name as a trademark without her consent and thus had misled the public into believing that she was the source of the cookbook.

Fern responded to this invasion of her territory in ways both typical and atypical of her earlier attempts to police her authorial persona. In her early career, she lacked the legal means to stop such incursions but cleverly turned that disadvantage into an advantage as she made the unauthorized use of her work a subject of her satiric columns. In 1856, however, Fern took legal action, and she made the violation and her action against the violator the subject of a column, "A Premonitory Squib before Independence" (2 August 1856).$^{19}$ Fern incorporates into her column a newspaper report ${ }^{20}$ briefly describing the legal basis of her claim of ownership of the Fanny Fern pseudonym, namely: "Mrs. Parton alleges that she is the 'Fanny Fern'; that all her writings are published under that name, and that she has acquired a special and only right to use it." The complaint filed with the court sets out in more detail the facts required to establish that possession: how and when she adopted the name, the sales of her books under that name, and the association in the public mind between the name and the literary productions bearing it. The inferior quality of Fleming's "ungrammatical, vulgar and commonplace" cookbook, Parton declares, will di-

\footnotetext{
${ }^{19}$ Tonkovich profitably discusses the suit as an instance of the problematics of naming for the woman author (Domesticity, pp. 45-48), but she relies entirely on Fern's column for the facts of the case.

${ }^{20}$ An identically worded report appeared in the 12 July 1856 Daily Pennsylvanian, which was most likely the first or one of several simultaneous early reports of the case in the Philadelphia press. According to the manuscript case file, the suit was entered on 11 July 1856 , and a special injunction was granted the same day; an order making the injunction permanent was entered on 31 October 1856 . Fern does not quote the court's opinion or order in the case, as Newbury and Tonkovich both seem to assume. There was no opinion, published or unpublished; the court simply granted Parton's request for a preliminary injunction without comment, thus implicitly affirming the legal reasoning presented by Fern's lawyers.
} 
minish her "Literary reputation" and impair future sales of works published under her pseudonym. ${ }^{21}$ Attached affidavits from Oliver Dyer and J. C. Derby attest to sales figures for books published under her control and carrying the Fanny Fern pseudonym, but no mention is made of its wide circulation in periodicals beyond her control or in the title of an unauthorized book, The Life and Beauties of Fanny Fern. ${ }^{22}$

Those potential challenges to her proprietary control do not appear in the manuscript record of the case or in Fern's representation of it in the Ledger. Instead, "A Premonitory Squib" constructs another version of the narrative Elizabeth Cady Stanton read in Ruth Hall of a woman writing her way out of bondage and into independence and self-possession. Fern begins the sketch by describing (in the continuous present tense) resistance from the lawyers she consults who tell her she has no legal claim to her name:

"FANNY FERN is not my name, is it?" Let me tell you, that if I originated it, as a nom de plume, I have as much right to the sole possession of it, as I have to the one I was baptised by; and no one has any more right to appropriate it, than to take the watch from my girdle. "Doubted?"-We shall see; I have listened to croakers before now, with my arms a-kimbo.

The remainder of the column touts her triumph over those doubters and over Fleming. The court confirms that her pseudonym is as much her personal property as the watch in her pocket, and, in her reading of the case, the court enforces not only the law of property but the rules of gentlemanly conduct.

\footnotetext{
${ }^{21}$ United States Circuit Court, Eastern District of Pennsylvania, "Parton v. Fleming," Archives folder 2-4/1856, National Archives, Mid-Atlantic Branch, Philadelphia, Pa.

${ }^{22}$ At the time of the publication of The Life and Beauties, there were no published decisions concerning the use of an author's name on a book featuring public domain materials. Later in the century, Washington Irving's nieces failed in their attempt to prevent publication of Irving's collected works (which had fallen into the public domain with the expiration of their copyright terms) without their permission by claiming trademark rights in the designation "Irving's Works" on the spine of the book. The court held that trademark rights in an author's name could not trump the expiration of copyrights. See G. P. Putnam's Sons v. Pollard \& Moss (1880), in Decisions of the United States Courts Involving Copyright and Literary Property, 1789-19o9, ed. Wilma S. Davis and Mark A. Lillis (Washington, D.C.: Copyright Office, 1980), pp. 2127-29.
} 
Fleming was not "honest, honorable, and chivalric" when he reached into her pocket and stole her name, Fern declares. In emphatic terms, she goes on to figure herself as a free and independent writing woman fully in possession of herself and her property:

Listen! All you who wear (blue) bonnets, and down on your grateful knees to me, for unfurling the banner of Women's (scribblers') Rights. Know, henceforth, that Violet Velvet, is as much your name (for purposes of copyright and other rights,) as Julia Parker, if you choose to make it so. ${ }^{23}$

Like the women at the Seneca Falls Convention, who drafted the Declaration of Sentiments by adapting the rhetoric of the Declaration of Independence to proclaim their independence from the tyranny of men, Fanny Fern declares her independent right to her name as property. In a related and typically complex and topical pun, Fern refers to the Philadelphia federal judge who decided her case, Judge John Kintzing Kane, and his record in a famous Fugitive Slave Law case:

\footnotetext{
${ }^{23}$ Despite Fern's invocation of "copy-rights" here, such a misappropriation of an author's name was not (and is not) an infringement of copyright, and the complaint filed in the case makes it clear that her lawyers did not argue that Fleming's appropriation of her name constituted copyright infringement. Newbury (Figuring Authorship, pp. 195-96), relying solely on Fern's newspaper accounts, identifies the case as a copyright infringement case and thus skews his interpretation. As George Ticknor Curtis noted in his treatise on copyright and literary property, the use of an author's name without an author's permission is "morally reprehensible," but it is not copyright infringement; only reproduction of the author's copyrighted text constitutes copyright infringement (A Treatise on the Law of Copyright [Boston: Charles C. Little and James Brown, 1847], p. 299). However, as Curtis also acknowledges, even though the author's copyright has not been infringed, such a misuse of the author's name, or, on a related note, the title of a work, can effectively impair the value of that which is protected by copyright, the right to print and sell copies of a book, or to authorize others to do so. Fern's complaint in the case claims precisely this-that the value of the copyrights in works she did author has been impaired by Fleming's use of her name on a book she did not author. For later reported cases on the question of the author's name as a trademark, see Bret Harte's successful suit against a publisher who sold a book including sketches by Harte and sketches not by Harte, presenting the volume as if Harte were the source of the entire volume's contents (Harte v. DeWitt [1874], in Decisions Involving Copyright, pp. 1201-2); and Mark Twain's failed attempt to use trademark law to thwart publication of some of his uncopyrighted newspaper sketches in a book bearing the name Mark Twain (Clemens v. Belford [1883], in Decisions Involving Copyright, pp. $647-51)$.
} 
What is the use of being a woman, if you can't carry a point? Are bonnets to be trampled on by boots? Judge Kane says No. May he live to Pass-more such decrees.

Just about the same time Judge Kane was hearing Parton's case, Passmore Williamson filed a suit against Kane in Pennsylvania state court. Williamson, a white abolitionist, charged that Kane had improperly imprisoned him for contempt of court a year earlier after he refused to produce the fugitive slaves he was suspected of harboring. ${ }^{24}$ In deploying the "Pass-more" pun, Fern figures herself both as slave and master. She is the slave, trampled by the boots of William Fleming and forced into involuntary servitude by his appropriation of her name and identity, whom Kane now manumits. She is also, however, the slavemaster, and Kane has decreed that her fugitive property (her "title") must be returned to her, its rightful owner.

But just as Fanny Fern seems to step forth as an authorial subject in full possession of herself and her property, she slips away. Her declaration of independence for herself and her scribbling sisters stands in silent conflict with the lead-in for the newspaper report she excerpts:

"FANNY FERN" BEFORE JUDGE KANE-In the United States District Court at Philadelphia, before Judge Kane on Friday, James Parton and Sara P. Parton, his wife, made application for a special injunction....

The title on the blue paper wrapper enveloping the manuscript case file swallows up her separate identity even more completely than the newspaper lead-in; the case title reads, "James Parton \& wife v. Wm. Fleming." Both Fanny Fern and Sara P. Parton disappear into the person of James Parton, becoming the unnamed appendage, "wife." Her declaration of indepen-

\footnotetext{
${ }^{24}$ Richard Hildreth included an account of the Passmore Williamson case as an appendix to his American edition of Atrocious Judges (New York: Miller, Orton \& Mulligan, 1856). A Philadelphia American Courier article, dated 2 August 1856, reports Williamson's suit against Kane in Delaware County Court; and a 27 July $185^{6}$ article in the Philadelphia Sunday Dispatch reports Williamson's visit to Moyamensing jail on the anniversary of his incarceration. For a brief biography, see Dictionary of American Biography, s.v. "Kane, John Kintzing."
} 
dence is an illusion. Her husband brought the suit because she, as a wife, had no separate legal existence. Even though Fern and her husband entered into a prenuptial agreement that allowed her to maintain ownership of and control over her copyrights, she still could not bring suit against Fleming without her husband's consent and full cooperation. ${ }^{25}$

Although Sara Parton's seemingly successful defense of her proprietorship could not fully succeed, given her marital status, I want to suggest in closing that that incomplete ownership of her intellectual property was not at all atypical among authors in nineteenth-century America. Although the same publishing laws and customs governed the circulation of male writers and their works, a woman writer's problematic relationship to publicity and property heightened her susceptibility to the effects of the marketplace. Not all periodical authors trading their wares were women, of course, but, as the metaphors used to describe Fern's situation often suggest, the American author's tenuous possession of self and property made an author like a woman. Judge Kane may have decreed that "bonnets" were not "to be trampled on by boots," but authors still remained, for the most part, in the position of "bonnets," susceptible to trampling by those having more power in the literary field and wearing heavy boots, namely publishers and readers.

A threat to Benjamin Shillaber's literary proprietorship illustrates the point. In 1853 , Shillaber's Mrs. Partington newspaper sketches were collected in an unauthorized book that also included "counterfeit" Mrs. Partington sketches. In its report on this doubly offensive publication, the Olive Branch had Mrs. Partington stand in for Shillaber and described the production of the bogus text as a violation of her person:

\footnotetext{
${ }^{25}$ For the common law of "coverture" and reform through the married women's property statutes, see Norma Basch, In the Eyes of the Law: Women, Marriage, and Property in Nineteenth-Century New York (Ithaca: Cornell University Press, 1982). Fanny Fern entered into a premarital contract with her third husband, James Parton, to carve out a "separate estate" to reserve for herself the right to control all of her copyrights acquired both before and after marriage (Warren, Fanny Fern, p. 153). However, James Parton's consent was necessary for this arrangement, and despite the private contractual arrangement, Sara's lawyers still found it necessary to enlist Parton as the primary plaintiff in the public forum of the court.
} 
Mrs. Partington has been the subject of one of the most heinous outrages ever perpetrated upon a female woman. Some shabby bookpublisher in New York thrust his hand into her ridicule [a Partingtonism for "reticule"], selected a few of her choicest sweets, and buried them among a heap of old Joe Miller's and other stale rubbish, the shape of a volume, to which he had the audacity to attach the old lady's name as god-mother! [31 December 1853]

The anecdote implies that to be an author of newspaper sketches is to be like Mrs. Partington, a woman alone in public carrying a purse and vulnerable to thieves.

During all of the years of Fern's literary career, the relationship of American authors to their intellectual property was publicly debated as authors repeatedly petitioned Congress in favor of international copyright and Congress repeatedly rejected their entreaties. ${ }^{26}$ On 28 November 1857 , in the New-York Ledger, Fern took a stand. Protesting the inaction of Congress and the president, she lambasted European publishers who "[put] their forefinger and thumb into my pocket, and [help] themselves." "It is the unprincipled principle of the thing," she protests, "the cool impudence of it-its is the idea that what's yours isn't yours." Fern, like all American authors, had recourse to the law to stave off the depredations of American publishers, but foreign publishers could filch with impunity. More effectively than most, Fanny Fern turned unauthorized circulation to her advantage, but we should not lose sight of the tenuousness of the hard-won and cleverly managed authorial ground she staked out for herself. That tenuousness is central to understanding both her particular situation and the broader situation of American authorship at a time when literary proprietorship was seldom secure, when all authors, like married women, could simultaneously claim their literary property and find themselves dispossessed of it. Fern's victory in court, while real,

\footnotetext{
${ }^{26}$ For the best account of the intemational copyright debates, see James J. Barnes, Authors, Publishers, and Politicians: The Quest for an Anglo-American Copyright Agreement, 1815-1854 (Columbus: Ohio State University Press, 1974).
} 
FANNY FERN AND LITERARY PROPRIETORSHIP 237 had its pyrrhic qualities as well, a circumstance that made her seem more like an author than less.

Melissa J. Homestead is the Mellon Post-Dissertation Fellow at the American Antiquarian Society in Worcester, Massachusetts. Beginning in August 2001, she will be an Assistant Professor of English at the University of Oklahoma in Norman. Her essay is derived from her book-in-progress, "Imperfect Title: Nineteenth-Century American Women Authors and Literary Property." 